\title{
Pengaruh Sinbiotik terhadap Penurunan Kadar C-Reactive Protein Serum Pasca operasi pada Anak Appendisitis Komplikata
}

\author{
Vita Indriasari, Bustanul Arifin Nawas, Dikki Drajat Kusmayadi, Rizki Diposarosa
}

\begin{abstract}
Appendicitis is the commonest cause of acute abdomen in children. Complicated appendicitis due to perforation associated with high morbidity. Several perioperative conditions fascilitated systemic inflammation and postoperative infectious complication. Synbiotic has a potential effect on reducing inflammatory response which reflected with lower serum c-reactive protein (CRP) level, so that the infectious complication could be avoided. This study aimed to observe the effect of synbiotic on postoperative serum CRP level reduction in children with complicated appendicitis. A randomized double blind study was done in 26 children with complicated appendicitis. The subjects were divided into synbiotic and placebo groups. Synbiotic was given 1 time preoperatively and continued 5 days afer surgery. Serum CRP level were examined preoperatively (CRP 0), postoperative day 1 (CRP 1), and 6 (CRP 6). Statistical analysis was done with Independent-t test $(p<0,05$ considered significan)t. The mean age of the patients was 9,85 years. The onset of abdominal pain was 3,92 days. The mean reduction of CRP $0-C R P 6$ between synbiotic and placebo group was 65,21\% $\pm 31,37$ SD vs 78,29\% $\pm 12,39 S D, p=0,073$; and the mean reduction of CRP $1-C R P 6$ was 73,54\% $\pm 22,04 v s 74,56 \%$ $\pm 17,58, p=0,897$. Wound infection was lower in synbiotic group (7,69\% vs 38,46\%). There was no difference in postoperative serum CRP level reduction between synbiotic therapy and placebo in children with complicated appendicitis (J I Bedah Indones. 2014;43:17-22).
\end{abstract}

Key words: synbiotic, complicated appendicitis, c-reactive protein

\section{Pendahuluan}

Appendisitis merupakan kondisi abdomen akut yang paling sering terjadi pada anak dan didiagnosis pada $1 \%$ sampai $8 \%$ penderita yang datang ke instalasi gawat darurat anak dengan keluhan nyeri perut. ${ }^{1,2}$ Walaupun demikian, diagnosis klinis sering kali terlambat sehingga terjadi perforasi appendiks yang berkembang menjadi appendisitis komplikata dengan peritonitis dan pembentukan abses intraabdomen. Appendisitis komplikata menyebabkan morbiditas yang tinggi (20\%-56\%) dengan komplikasi infeksi sebagai penyebab utama. ${ }^{3,4}$

Beberapa kondisi perioperatif pada appendisitis komplikata memfasilitasi terjadinya depresi sistem imun, inflamasi sistemik, dan translokasi bakteri sehingga berperan dalam terjadinya komplikasi infeksi pasca operasi. Faktor-faktor tersebut antara lain: 1) kebocoran mikroflora endogen saluran cerna

Alamat Korespondensi

Vita Indriasari, dr., SpBA.

Alamat: Setraduta L3 no. 10, Bandung.

e-mail: vitabustanul@yahoo.com ke dalam rongga peritoneum; 2) penurunan motilitas usus pasca operasi; 3) trauma operasi dan manipulasi usus; dan 4) digunakannya peralatan invasif. ${ }^{5,6}$

Derajat inflamasi yang tinggi secara signifikan berhubungan dengan peningkatan risiko terjadinya inflamasi sistemik. Peningkatan tumor necrosis factor (TNF)- $\alpha$ dan interleukin (IL)-6 sebanyak enam kali atau lebih berhubungan dengan kejadian komplikasi infeksi pasca operasi. C-reactive protein (CRP) merupakan protein plasma yang berpartisipasi dalam respon inflamasi sistemik. Penurunannya merupakan indikator yang baik dalam resolusi inflamasi sistemik. ${ }^{7,8}$

Sinbiotik merupakan kombinasi probiotik dan prebiotik yang memberikan manfaat pada inang dengan memengaruhi mekanisme patogenesis translokasi bakteri. Sinbiotik meningkatkan motilitas usus, menstabilisasi sawar usus, dan memodulasi sistem imun inang. Pada kondisi akut, sinbiotik mengendalikan inflamasi dan sepsis pada penderita penyakit kritis, trauma multipel, pankreatitis, inflammatory bowel disease, dan lain-lain. Sinbiotik juga menurunkan 
komplikasi infeksi pasca operasi pada berbagai kondisi bedah. ${ }^{9-16}$

Melalui perannya dalam memodulasi sistem imun, sinbiotik diperkirakan berpotensi dalam menurunkan respon inflamasi pasca operasi pada anak appendisitis komplikata, yang dicerminkan oleh penurunan CRP, sehingga diharapkan dapat menurunkan kejadian komplikasi infeksi pasca operasi. Tujuan penelitian ini adalah mempelajari perbedaan penurunan kadar CRP serum pasca operasi antara pemberian sinbiotik dan plasebo pada anak appendisitis komplikata.

\section{Metode}

Penelitian ini merupakan uji klinis acak tersamar ganda untuk menilai efek sinbiotik terhadap penurunan kadar CRP serum pasca operasi pada penderita appendisitis komplikata. Penelitian ini telah menda patkan rekomendasi persetujuan etik oleh Komite Etik dan Penelitian Kesehatan RSUP Dr. Hasan Sadikin Bandung. Subyek penelitian adalah anak berusia 0-14 tahun yang didiagnosis appendisitis komplikata secara klinis yang kemudian dilakukan appendektomi per laparotomi. Penderita yang menderita penyakit inflamasi lain selain appendisitis, menderita penyakit kritis, keganasan, autoimun, dan keadaan immunocompromised lain dieksklusi.

Setelah diagnosis, penderita appendisitis komplikata disiapkan untuk operasi. Persiapan tersebut berupa puasa, pemberian cairan intravena, koreksi gangguan elektrolit, dan pemberian antibiotik seftriakson dan metronidazol. Pada saat ini, pada kedua kelompok dilakukan pemeriksaan kadar CRP serum (CRP 0).

Enam jam sebelum operasi, penderita diberikan larutan sinbiotik atau plasebo. Serbuk sinbiotik Liprolac ${ }^{\circledR}$ Kalbe (mengandung probiotik $1,25 \times 10^{6} \mathrm{CFU}$ yang terdiri dari: Streptococcus thermophilus $6,8 \times 10^{8} \mathrm{CFU}$, Lactobacillus rhamnosus $2 \times 10^{8} \mathrm{CFU}$, Lactobacillus acidophilus $2 \times 10^{8} \mathrm{CFU}$, Bifidobacterium longum

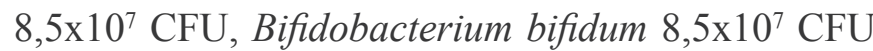
dan prebiotik yang terdiri dari: polidekstrosa 869,63 $\mathrm{mg}$, frukto-oligosakarida $375 \mathrm{mg}$, dan campuran serbuk laktulosa $125 \mathrm{mg}$ ) dilarutkan ke dalam air minum secukupnya, dan diberikan secara oral atau melalui selang nasogastrik. Dilakukan operasi appendektomi per laparotomi.
Pasca operasi, selang nasogastrik dilepas bila pen derita tidak kembung dan fungsi saluran cerna mulai kembali. Semua penderita menerima clear fluid pada hari pertama pasca operasi bila tidak ditemukan distensi abdomen dan muntah. Penderita diberikan analgetik dan antibiotik intravena selama 5 hari, dilanjutkan dengan antibiotik oral selama 7 hari. Kateter uretra dilepas pada hari pertama setelah operasi. Hari ke-2 pasca operasi penderita diberikan larutan sinbiotik atau plasebo sebanyak 1 kali per hari selama 5 hari. Pasca operasi, kadar CRP serum diperiksa pada hari ke-1 (CRP 1) dan hari ke-6 (CRP 6). Data demografi penderita dicatat. Komplikasi pasca operasi diobservasi selama 2 minggu yang meliputi infeksi luka operasi, abses intraabdomen, dan obstruksi usus halus adhesif.

\section{Uji Statistik}

Dilakukan perbandingan persentase penurunan CRP 0 - CRP 6, serta persentase penurunan CRP 1 - CRP 6 antara kelompok sinbiotik dan plasebo.Seluruh data pada kedua kelompok akan dilakukan uji normalitas dengan uji Kolmogorov Smirnov dan uji homogenitas dengan uji Levene. Data yang normal selanjutnya dilakukan uji dengan t-independent sedangkan bila data tidak normal digunakan uji alternatif yaitu Mann Whitney. Nilai signifikansi $\mathrm{P}<0,05$ adalah signifikan.

\section{Hasil}

Pada penelitian ini didapatkan 26 subyek yang terbagi menjadi kelompok sinbiotik dan plasebo. Data demografi diterangkan pada Tabel 1.

Hasil perbandingan persentase penurunan CRP $0-$ CRP 6 dan CRP 1 - CRP 6 antara kelompok sinbiotik dengan kelompok plasebo menunjukkan tidak terdapat perbedaan yang bermakna pada penurunan CRP preoperasi dan hari ke-6 pasca operasi $(\mathrm{p}=0,175)$ maupun penurunan CRP hari ke-1 pasca operasi dan hari ke-6 pasca operasi antara kelompok sinbiotik dan kelompok plasebo $(\mathrm{p}=0,897)($ Tabel 2).

Infeksi luka operasi didapatkan pada 1 kasus dari kelompok sinbiotik $(7,69 \%)$ dan 5 kasus dari kelompok plasebo (38,46\%). Obstruksi usus halus adhesif didapatkan pada 1 kasus pada kelompok plasebo (7,69\%), sedangkan abses intraabdomen tidak terjadi pada seluruh penderita. 
Tabel 1. Data Demografi

\begin{tabular}{lccc}
\hline & Keseluruhan & $\begin{array}{c}\text { Kelompok } \\
\text { Sinbiotik }\end{array}$ & $\begin{array}{c}\text { Kelompok } \\
\text { Plasebo }\end{array}$ \\
\hline Jenis kelamin & & & \\
$\quad$ Laki-laki (\%) & 53,8 & 46,1 & 69,2 \\
$\quad$ Perempuan (\%) & 46,2 & 53,9 & 31,8 \\
Usia (rerata \pm SB) & $9,85 \pm 2,25$ & $9,46 \pm 1,94$ & $10,23 \pm 2,55$ \\
Onset nyeri perut (hari, rerata \pm SB) & $3,92 \pm 1,32$ & $3,61 \pm 1,44$ & $4,23 \pm 1,16$ \\
Diagnosis & & & \\
$\quad$ Peritonitis generalisata (\%) & 26,9 & 23,1 & 30,7 \\
$\quad$ Peritonitis lokal (\%) & 73,1 & 76,9 & 69,3 \\
$\quad$ Abses periappendiks (\%) & 0 & 0 & 0 \\
Jumlah pus (cc, rerata \pm SB) & $63,07 \pm 42,40$ & $52,30 \pm 30,59$ & $73,84 \pm 50,75$ \\
CRP preoperasi (gr/dL, rerata \pm SB) & $119,91 \pm 81,37$ & $198,91 \pm 96,88$ & $159,41 \pm 96,47$ \\
\hline
\end{tabular}

Tabel 2. Perbandingan Persentase Penurunan CRP antara Kelompok Sinbiotik dan Kelompok Plasebo

\begin{tabular}{cccc}
\hline \multirow{2}{*}{ Variabel } & \multicolumn{2}{c}{ Kelompok } & \\
& Sinbiotik & Plasebo & Nilai p \\
& Rerata \pm SB & Rerata \pm SB & \\
\hline \% penurunan CRP 0 - CRP 6 & $65,21 \pm 31,37$ & $78,29 \pm 12,39$ & 0,073 \\
\% penurunan CRP 1 - CRP 6 & $73,54 \pm 22,04$ & $74,56 \pm 17,58$ & 0,897 \\
\hline
\end{tabular}

\section{Diskusi}

Pada penelitian ini, onset nyeri perut sampai penderita datang berobat ke rumah sakit memiliki rerata 3,92 hari. Berdasarkan perjalanan penyakit appendi sitis, waktu mulai dari inflamasi appendiks sederhana sampai terjadi perforasi adalah 24 sampai 36 jam dari gejala awal dan formasi abses setelah 2 sampai 3 hari. Hal ini sesuai dengan penelitian Cappendijk dan Hazebroek dimana pada 129 kasus appendisitis yang mengalami keterlambatan diagnosis, sebanyak $71 \%$ mengalami perforasi sehingga berkembang menjadi appendisitis komplikata dengan disertai peritonitis atau pembentukan abses. ${ }^{1-4}$

Beberapa penelitian menunjukkan peran probiotik dan sinbiotik dalam menurunkan inflamasi sistemik pada kasus-kasus bedah. Pada penderita trauma multipel kejadian inflamasi dan infeksi lebih rendah dengan diikuti oleh penurunan leukosit, endotoksin, dan kadar CRP pada kelompok terapi sinbiotik dibandingkan dengan kontrol. Penelitian mengenai efek sinbiotik perioperatif pada pasien yang dilakukan hepatektomi menunjukkan bahwa IL-6, dan CRP pasca operasi lebih rendah pada kelompok sinbiotik dibandingkan dengan kontrol $(\mathrm{p}<0.1)$. Pada operasi kanker abdomen, terjadi penurunan jumlah infeksi, $\mathrm{CRP}$, dan jumlah leukosit pada pasien yang diberi- kan dengan probiotik dibandingkan dengan penderita yang diberikan plasebo, nutrisi parenteral. ${ }^{15,17,18}$

Pada penelitian ini, tidak terdapat perbedaan yang bermakna pada penurunan kadar CRP preoperasi dan hari ke- 6 pasca operasi $(p=0,073)$, serta penurunan kadar CRP hari ke-1 pasca operasi dan hari ke-6 pasca operasi antara kelompok sinbiotik dan kelompok plasebo $(\mathrm{p}=0,897)$. Hasil ini bertentangan dengan penelitian sebelumnya oleh Usami dan Giamarellos dimana pada kelompok sinbiotik didapatkan penurunan penanda inflamasi sistemik pasca operasi seperti CRP dan IL-6 yang lebih besar dibandingkan dengan kontrol. ${ }^{15,17,18}$ Hasil penelitian ini lebih sesuai dengan temuan Anderson dkk yang meneliti efek sinbiotik pada translokasi bakteri, kolonisasi gaster, inflamasi sistemik, dan morbiditas sepsis pada penderita bedah elektif dewasa. Subyek diberikan 3 kali per hari dan prebiotik $4 \times 10^{9}$ Lactobacilus acidophilus, Lactobcilus bulgaricus, Bifidobacterium lactis, dan Streptococcus thermophiles, serta oligofruktosa 1-2 minggu preoperasi,kemudian dilanjutkan pemberiannya pasca operasi selama ditoleransi penderita. Respon inflamasi sistemik dilihat dari CRP dan IL-6 yang diambil dari serum penderita pada hari ke-1 dan ke-6 pasca operasi. Kedua kelompok plasebo dan sinbiotik me nunjukkan peningkatan yang signifikan pada CRP 
dan IL-6 pada hari pertama pasca operasi. Pada hari ke-7, kadar IL-6 menurun sampai ke nilai preoperasi namun kadar CRP tetap meningkat. Tidak terdapat perbedaan yang signifikan antara kedua kelompok dalam penurunan IL-6 dan CRP. ${ }^{19}$

Pada penelitian ini tidak terlihat efek imunomodulasi yang ditunjukkan oleh CRP sebagai penanda inflamasi sistemik. Kemungkinan hal ini disebabkan oleh besarnya cedera operasi yang mencegah deteksi efek imunomodulasi. Modulasi respon imun tersebut kemungkinan juga dapat menjadi terdeteksi beberapa minggu atau bulan setelah pemberian sinbiotik, mengingat pendeknya durasi pemberian sinbiotik pada penelitian ini. Kemungkinan lain adalah perbedaan dalam komposisi, dosis, serta cara pemberian sinbiotik pada penelitian ini dibandingkan dengan penelitan-penelitian sebelumnya. Sebagai tambahan, walaupun penulis telah berusaha meminimalisir faktor-faktor perancu, namun masih terdapat kemungkinan adanya kondisi inflamasi lain yang dapat me mengaruhi nilai CRP.

Pada penelitian ini digunakan larutan sinbiotik Liprolac $^{\circledR}$ yang dalam setiap kemasan mengandung 2,5 gram mikroorganisme hidup (probiotik) dengan jumlah 1,25x106 CFU yang terdiri dari: Streptococcus thermophilus 6,8x108 CFU, Lactobacillus rhamnosus 2x108 CFU, Lactobacillus acidophilus 2x108 CFU, Bifidobacterium longum 8,5x107 CFU, Bifidobacterium bifidum 8,5x107 CFU dan prebiotik yang terdiri dari: polidekstrosa $869,63 \mathrm{mg}$, frukto-oligosakarida $375 \mathrm{mg}$, dan campuran serbuk laktulosa 125 mg. Dosis yang diberikan adalah 1 kali per hari, pada saat preoperasi dan dilanjutkan pasca operasi selama 5 hari. Dasar pemilihan formula sinbiotik tersebut adalah sebagai berikut: (1) mengandung probiotik multistrain yang lebih efektif dibandingkan dengan probiotik multistrain20; (2) mengandung probiotik masing-masing dengan dosis sekitar 106 sampai 107 CFU per gram sehingga sufisien mencapai usus halus dan kolon20; (3) mengandung prebiotik FOS dan laktulosa yang merupakan prebiotik dengan efek yang paling konsisten dalam berbagai penelitian21-23, (4) Pemberian probiotik perioperatif selama 6 hari $(B i-$ fidobacterium longum dan Lactobacillus johnsonii) memodulasi imunitas inang dengan ekspresi CD3,
CD4, CD8, dan limfosit naif dan memori yang lebih banyak. ${ }^{11}$

Masih sedikit data yang memaparkan regimen pemberian sinbiotik yang tepat pada kasus akut bedah anak. Sebagian besar penelitian dilakukan pada penderita bedah elektif sehingga sinbiotik dapat diberikan perioperatif dalam jangka waktu lama. Penelitian pada penderita anak terbatas pada kasus short bowel syndrome, enterokolitis terkait penyakit Hirschsprung, enterokolitis nekrotikan, dan kondisi medis lainnya yang tidak memerlukan operasi segera. Lama waktu pemberian, dosis, dan komposisi sinbiotik untuk mencegah komplikasi infeksi pasca operasi bervariasi pada berbagai penelitian dan belum ada pedoman yang tetap. Sebagai contoh, penelitian pada penderita pasca operasi abdomen mayor, diberikan sinbiotik berupa Lactobacilus plantarum dan serat gandum selama 5 hari pasca operasi. Penelitian pada penderita yang dilakukan transplantasi hati, diberikan sinbiotik Lactobacilus plantarum dan 4 serat selama 12 hari pasca operasi. Penelitian pada penderita pascahepatektomi, diberikan Bifidobacterium brevis, Lactobacilus casei dan serat. ${ }^{20}$ Usami menggunakan sinbiotik berupa probiotik 3 gram per hari yang terdiri dari: Yakult BL Seichoyaku 1x108 CFU/ gram dan Lactobacillus 1x108 CFU/gram, serta GOS 10 gram per hari pada penelitiannya pada penderita pasca operasi reseksi hati. Sinbiotik diberikan selama 14 hari preoperasi dan dilanjutkan pasca operasi pada hari ke 3 sampai 14. Giamarellos pada penelitiannya pada penderita pascaprosedur Whipple menggunakan 4 bakteri asam laktat yang berbeda, ditambah 4 serat yaitu: betaglukan, inulin, pektin, ragi. Sinbio tik diberikan 1 hari preoperasi dan dilanjutkan pasca operasi selama 8 hari.16,17 Secara umum pada kasus bedah untuk menurunkan komplikasi infeksi pasca operasi, probiotik diberikan dalam dosis 5x107 CFU sampai 4x109 CFU. ${ }^{24,25}$

Pada penelitian ini, sinbiotik tidak menunjukkan efek antiinflamasinya yang ditunjukkan oleh penurunan kadar CRP pasca operasi secara signifikan. Namun, terlihat fenomena yang menarik dimana kasus infeksi luka operasi lebih sedikit terjadi pada kelompok sinbiotik dibandingkan dengan plasebo. Hasil tersebut sesuai dengan beberapa penelitian sebelumnya dimana 
komplikasi infeksi pasca operasi lebih rendah pada penderita yang mendapatkan terapi sinbiotik. Pada penelitian ini dapat dilihat bahwa keadaan inflamasi sistemik preoperasi pada kelompok sinbiotik lebih rendah dibandingkan plasebo. Hal ini ditunjukkan oleh onset nyeri perut yang lebih dini, diagnosis peritonitis generalisata yang lebih sedikit, rerata jumlah pus yang lebih sedikit, dan kadar CRP preoperasi yang lebih rendah pada kelompok sinbiotik. Becher dkk mengemukakan bahwa derajat inflamasi yang tinggi pada fase awal berhubungan dengan komplikasi infeksi pada perjalanan penyakit selanjutnya dan begitu pula sebaliknya. ${ }^{7}$ Mungkin hal ini dapat menjawab pertanyaan, dimana pada penelitian ini sinbiotik tidak menunjukkan efek menurunkan inflamasi sistemik namun dapat menurunkan kejadian komplikasi infeksi.

\section{Kesimpulan}

Penurunan kadar CRP serum pasca operasi tidak lebih besar pada pemberian sinbiotik dibandingkan dengan plasebo pada anak appendisitis komplikata.

\section{Daftar Pustaka}

1. Reynolds SL, Jaffe DM. Diagnosing Abdominal Pain in a Pediatric Emergency Department. Pediatr Emerg Care. 1992; $8: 126-8$.

2. Dunn JYC. Appendicitis. Dalam Grosfeld JL, O’Neill JA, Coran AG, Fonkalsrud EW (penyunting). "Pediatric Surgery” Edisi ke-6. Philadelphia: Mosby Elsevier. 2006; h. 1501-31.

3. Cappendijk VC \& Hazebroek FWJ. The Impact of Diagnostic Delay on the Course of Acute Appendicitis. Arch Dis Child. 2000; $83: 64-6$.

4. Ozguner IF, Buyukayavuz BI, Savas MC. The Influence of Delay on Perforation in Childhood Appendicitis: a Retrospective Analysis of 58 Cases. Saudi Med J. 2004; 25(9) : 1232-6.

5. Saracoglu A, Saracoglu KT, Aylu B, Fidan V. Delayed Treatment of Appendectomy that Causes Systemic Inflammatory Response Syndrome: a Rare Complication. Health. 2011; 3( 2) : 116-7.

6. Rayes N, Seehofer D, Theruvath T, Mogl M, Langrehr JM, Nussler NC, dkk. Effect of Enteral Nutrition and Synbiotics on Bacterial Infection Rates After Pylorus-Preserving Pancreatoduodenectomy: a Randomized, Double Blind Trial. Ann Surg. 2007; $246:$ 36-41.
7. Becher RD, Hoth JJ, Miller PR, Meredith JW, Chang MC. Systemic Inflammation Worsens Outcomes in Emergency Surgical Patients. J Trauma Acute Care Surg. 2012; 72(5) : 1140-9.

8. Seligman R, Meisner M, Lisboa TC, Hertz FT, Flippin TB, Fachel JMG. Decreases in Procalcitonin and C-Reactive Protein are Strong Predictors of Survival in Ventilator-Associated Pneumonia. Critical Care. 2006; 10(5) : 1-9.

9. Nomoto K. Prevention of Postoperative Microbial Infection by Synbiotics. Ind J Experiment Biol. 2008; 46 : 557-61.

10. Giamarellos-Bourboulis EJ, Bengmark S, Kanellakopoulou K, Kotzampassi K. Pro- and Synbiotics to Control Inflammation and Infection in Patients with Multiple Injuries. J. Trauma. 2009; $67:$ 815-21.

11. Gianotti L, Morelli L, Galbiati F, Rocchetti S, Coppola S, Beneduce A, dkk. A Randomized Double-Blind Trial on Preioperative Administration of Probiotics in Colorectal Cancer Pantients. World J Gastroenterol. 2010; 16(2) : 167-75.

12. Bengmark S. Pro- and Synbiotics for Prevent Sepsis in Major Surgery and Severe Emergencies. Nutrients. 2004; 4 : 91-111.

13. Faraj M \& Salem N. "C-Reactive Protein”. Blood cell-an overview of studies in hematology. Intech open science. 2012; melalui http://dx.doi.org/10.5772/47735 [12/10/12]

14. Pancer G, Engelman E, Hoque F, Alam M, Rucinski J, Bernstein LH. C-Reactive Protein for Enhanced Evaluation of the Systemic Inflammatory Response Syndrome (SIRS). The Open Clin Chem J. 2011; 4 : 1-9.

15. Seligman R, Meisner M, Lisboa TC, Hertz FT, Flippin TB, Fachel JMG. Decreases in Procalcitonin and C-Reactive Protein are Strong Predictors of Survival in Ventilator-Associated Pneumonia. Critical Care. 2006; 10(5) : 1-9.

16. Usami M, Miyoshi M, Kanbara Y, Aoyama M, Sakaki H, Shuno K. Effect of Perioperative Symbiotic Treatment on Infectious Complication, Intestinal Integrity, and Fecal Flora and Organic Acids in Hepatic Surgery with or without Cirrhosis. J Parenter Enteral Nutr. 2001; 35(3) : 317-28.

17. Giamarellos-Bourboulis EJ, Bengmark S, Kanellakopoulou K, Kotzampassi K. Pro- and Synbiotics to Control Inflammation and Infection in Patients with Multiple Injuries. J. Trauma. 2009; 67 : 815-21.

18. Usami M, Miyoshi M, Kanbara Y, Aoyama M, Sakaki H, Shuno K. Effect of Perioperative Symbiotic Treatment on Infectious Complication, Intestinal Integrity, and Fecal Flora and Organic Acids in Hepatic Surgery with or without Cirrhosis. J Parenter Enteral Nutr. 2001; 35(3) : 317-28.

19. Anderson ADG, McNaught CE, Jain PK, MacFie J. Randomized clinical trial of symbiotic therapy in elective surgical 
patients. Gut. 2004; 53:241-245.

20. Deshpande GC, Rao SC, Keil AD, Patole SK. EvidenceBased Guidelines for Use of Probiotics in Preterm Neonates. BMC Medicine. 2011; 9(92) : 1-55.

21. Crittenden R, Playne MJ. Prebiotics. Effects on Human Health and Desease. Dalam: Lee YK, Salminen S "Handbook of Probiotics and Prebiotics”, Edisi ke-2. New Jersey: John Wiley and Sons. 2009; h. 567-569

22. Birkett Am, Francis CC. Short-Chain Fructo-Oligosaccharide: A Low Molecular Weight Fructan. Dalam: Cho SS, Finocchioro ET "Handbook of Prebiotics and Probiotics Ingredients Health Benefits and Food Applications”. Boca Raton: CRC Press. 2010; Hal 13-42.

23. Nauta A, Bakker-Zierikzee AM, Schoterman MHC. GalactoOligosaccharide. Dalam: Cho SS, Finocchioro ET "Handbook of Prebiotics and Probiotics Ingredients Health Benefits and Food Applications". Boca Raton: CRC Press. 2010; h. 75-94.

24. Sander ME, Akkermans LMA, Haller D, Hammerman C, Heimbach J, Hormannsperger G, dkk. Safety Assessment of Probiotics in Human. Gut Microbes. 2010; 1(3) : 164-185

25. Lee YK. Effective Dosage for Probiotic Effects. Dalam: Lee YK, Salminen S "Handbook of Probiotics and Prebiotics", Edisi ke-2. New Jersey: John Wiley and Sons. 2009; h.226270 